THE CYBERNETIC THEORY OF DECISION 


\section{The Cybernetic Theory of Decision}

New Dimensions of Political Analysis

With a new preface by the author JOHN D. STEINBRUNER

PRINCETON UNIVERSITY PRESS

PRINCETON AND OXFORD 
Copyright (C) 1974 by Princeton University Press

Published by Princeton University Press, $4 \mathrm{I}$ William Street, Princeton, New Jersey 08540

In the United Kingdom: Princeton University Press, 3 Market Place, Woodstock, Oxfordshire OX20 ISY

All Rights Reserved

First paperback edition, 1976

Second paperback edition, with a new preface, 2002

Library of Congress Cataloging-in-Publication Data

Steinbruner, John D., I94 I-

The cybernetic theory of decision : new dimensions of political analysis /

John D. Steinbruner; with a new preface by the author.

p. cm.

Originally published: Princeton, N.J. : Princeton University Press, I974.

Includes bibliographical references and index.

ISBN o-69r-09487-X (pbk. : alk. paper)

I. Political science-Decision making. 2. Nuclear weapons. 3. North Atlantic Treaty Organization. I. Title.

$$
\begin{gathered}
\mathrm{JA}_{74.5} . \mathrm{S}_{74} 2002 \\
65^{8} 8.4^{\prime} \mathrm{O} 3^{\prime} \mathrm{OI}-\mathrm{dc2} \mathrm{I}
\end{gathered}
$$

British Library Cataloging-in-Publication Data is available

This book has been composed in Linotype Janson

Printed on acid-free paper. $\infty$

www.pupress.princeton.edu

Printed in the United States of America

$\begin{array}{llllllllll}\text { I } & 3 & 5 & 7 & 9 & \text { IO } & 8 & 6 & 4 & 2\end{array}$ 
In memory of Abram Chayes 
